\title{
Students' Perception on the Implementation of Online Project-Based Learning in Teaching $4 \mathrm{Cs}$
}

\author{
Amanda Ummu Haniah ${ }^{1}$, Ngadiso $^{2}$, Endang Setyaningsih 3 \\ ${ }^{1}$ Universitas Sebelas Maret, Indonesia.e-mail:amanda.ummu@student.uns.ac.id \\ 2Universitas Sebelas Maret, Indonesia.e-mail:ngadisodok@yahoo.com \\ 3Universitas Sebelas Maret, Indonesia.e-mail:endang_setyaningsih@staff.uns.ac.id
}

\begin{tabular}{|c|c|}
\hline ARTICLE INFO & ABSTRACT \\
\hline $\begin{array}{l}\text { Keywords: } \\
\text { Communication, } \\
\text { Collaboration, Creativity, } \\
\text { Critical Thinking, Online } \\
\text { PBL }\end{array}$ & $\begin{array}{l}\text { Project-based Learning is still being a prominent method to be investigated. } \\
\text { As the rapid advancement of technology has resulted in a more user-friendly } \\
\text { virtual learning environment, this study aimed to investigate the } \\
\text { implementation of Online PBL in teaching } 4 \text { Cs. A total of } 33 \text { fifth-semester } \\
\text { students, } 22 \text { females \& } 11 \text { males, of a public university in Central Java were } \\
\text { involved in this study. Observation and Likert-scale questionnaires were } \\
\text { employed in collecting the data. By calculating the overall score per item, the } \\
\text { data were analyzed using descriptive statistics. The result of this study shows } \\
\text { five stages of Online PBL implementation starting from selecting the topic } \\
\text { and the purpose, outlining the project, rehearsing the product, presenting the } \\
\text { product, and assessing the product. Online PBL helps students to master } \\
\text { creativity and innovation skills, communication skills, critical thinking skills, } \\
\text { and collaboration skills. Based on the positive responses from students, } \\
\text { Online PBL becomes a suggested method for assisting students in acquiring } \\
\text { the } 4 \text { Cs. }\end{array}$ \\
\hline \multicolumn{2}{|c|}{$\begin{array}{l}\text { How to cite: } \\
\text { Haniah, A. U., Ngadiso, N., \& Setyaningsih, E. (2021). Students' Perception on the Implementation of } \\
\text { Online Project-Based Learning in Teaching 4Cs. Indonesian Journal of English Language Teaching and } \\
\text { Applied Linguistics, 6(1), 123-140 }\end{array}$} \\
\hline
\end{tabular}

\section{Introduction}

Project-based learning which was based on John Dewey's idea of 'learning by doing' (1897) has become one of the most prominent methods as well as one of the most widely researched subjects. In the past 5 years, more than 1,500,00 studies related to PBL in different contexts are recorded in Google Scholar only. Those empirical investigations mostly revealed that the implementation of PBL resulted in positive gains. This is confirmed by a 20-year metaanalysis of 30 journal articles on PBL by Chen \& Yang (2019). The highlighted results of the meta-analysis include a medium-to-large mean effect size (0.71) for student achievements. Guo et al. (2020) had also conducted a review of 76 empirical studies on PBL, focusing on 
learning outcomes. The review discovered four categories of learning outcomes from the PBL implementation: affective, cognitive, artifact performances, and behavioral outcomes. Most of the reviewed studies ( 68 of 76 ) discussed the affective outcomes. PBL has been related to increasing academic achievement (Boaler, 1998; Panasan et al., 2010; Schneider et al., 2002).

PBL is an instructional method that allows students to actively participate in an authentic inquiry of real-world and open-ended problems (Barak \& Yuan, 2021). What is intended by a project in project-based learning is a wide variety of assignments that combine language skills through some activities (Fauziati, 2014). Projects in PBL require students to engage in inquiry, solution building, and collaboration to help address real-world issues or challenges. The teacher's role shifts to facilitator or project manager, students are encouraged to decide how best they do their work. Chen \& Yang (2019) mentioned some fundamental features of PBL: 1) inquiry, led by the driving question: students raise their own questions, conduct some research, and create solutions; 2 ) student voice and choice: students are encouraged to take charge of the project's execution; 3 ) revision and reflection: teachers or students may provide feedback in order to improve the products, and students might evaluate what and how they are learning; and 4) publicly presented product: students do a public presentation of their product.

PBL has been recommended in learning English because it is known to be an effective method for resolving problems in the 21st-Century education field (Fauziati, 2014). 21stCentury skills have a wide range of frameworks. Some organizations have a different framework about 21st skills, but they share the same general theme. International organizations that develop 21st-Century skills frameworks are including the Organization for Economic Cooperation and Development (OECD), Assessment and Teaching of twenty-firstcentury Skills (ATCS), and Partnership for 21st-Century Learning ( $\left.P_{21}, 2019\right)$. The OECD approach focuses on cognitive skills, intrapersonal skills, interpersonal skills, and technical skills (Geisinger, 2016). Meanwhile, the $P_{21}$ initiative identified 21st-Century central into core subjects and 21st-Century themes, learning and innovation skills, life and career skills, and information, media, and technology skills (Bourn, 2018). OECD focuses more on technical and vocational education while $P_{21}$ is more related to formal education (Bourn, 2018).

This study focuses on the 21st-Century skills proposed by Partnership for 21st-Century Learning ( $\mathrm{P}_{21}$ ) particularly on the learning and innovation skills which are known as ${ }_{4} \mathrm{Cs}$ to refer to formal education and curriculum. Moreover, $\mathrm{P}_{21}$ is considered the most influential of the various initiatives promoting 21st-Century (Bourn, 2018). Based on the P21 (2019), learning and innovations skills (the ${ }_{4} \mathrm{Cs}$ ) cover creativity, critical thinking and problemsolving, communication, and collaboration. Saxena (2014) conveyed that those 4 Cs super skills for the twenty-first century assist students to develop the qualities needed for success in college, career, and citizenship. As a result, those skills must be incorporated into curriculum design, taught, and evaluated in education or anywhere else (Geisinger, 2016). According to Songkram et al. (2019), "when instructors would like to develop students to have twenty-first-century skills, three areas are typically involved: (1) learning and innovation skills, (2) information media and technology skills, and (3) life and career skills".

As a recommended method for solving problems in 21st-century education, PBL can improve critical thinking, problem-solving, and communication skills (Fauziati, 2014). When students solve a real-world problem, PBL fosters collaboration and communication skills in the 21st- 
Century and respects students' learning styles or interests (Bell, 2010). Some studies found that PBL gives a positive impact on $21^{\text {st }}$ Century skills, namely communication (Çakiroğlu \& Erdemir, 2019; Owens \& Hite, 2020; Rochmawati et al., 2019), collaboration (Çakiroğlu \& Erdemir, 2019; Rochmawati et al., 2019), critical thinking (Bell, 2010; Cortázar et al., 2021), and creativity (Barak \& Yuan, 2021; Bell, 2010; Rochmawati et al., 2019).

In the earlier study, the PBL method was mainly carried out in the offline learning setting and little is known about PBL in an online learning environment. The outbreak of the COVID-19 pandemic in 2020 abruptly demanded all the educational institutions to conduct the teaching and learning activities from home. Schools and universities in Indonesia have had a difficult academic year in 2019-2020. The cessation of face-to-face classes in Indonesia began in midMarch 2019 due to a widespread outbreak of the coronavirus. Because of the suspension, schools and colleges agreed that classes had to be taught completely online initially, and later for the next semester. As courses were structured for face-to-face teaching, the educators needed to adapt them to fit online learning (Moorhouse, 2020). Based on the previous studies, it turns out that there has been no research related to the implementation of online project-based learning in teaching ${ }_{4} \mathrm{Cs}$, especially in a full online learning context during the COVID-19 emergency. Therefore, this research tries to investigate online project-based learning implementation in teaching $4 \mathrm{Cs}$ and students' perceptions towards it.

This study sheds light on how PBL can be implemented to teach 21st-century skills under such a challenging context by responding to the following research questions:

1. How was the implementation of online project-based learning in teaching ${ }_{4} \mathrm{Cs}$ ?

2. What are the student's perceptions toward the implementation of online projectbased learning in teaching $4 \mathrm{Cs}$ ?

\section{Theoretical framework}

\subsection{The ${ }_{4} \mathrm{Cs}$}

The focus of educators today is to equip students with 21st-century skills (Zakaria et al., 2016). Partnership for 21st-Century Learning (P21) is considered the most well-known of the several projects fostering 21st-Century Skills (Bourn, 2018). As the most prominent and wellknown framework of 21st-Century skills in the field of information technology in education (Chu et al., 2016), P21 classified eleven skills into three gist elements:

- Learning and Innovation: The ${ }_{4} \mathrm{Cs}$ - creativity and innovation, critical thinking and problem-solving, and communication and collaboration.

- Information, media, and technology skills: Information literacy, media literacy, and information and communication technology literacy.

- Life and career skills: Flexibility \& adaptability, productivity and accountability, social and cross-cultural engagement, initiative and self-direction, and leadership and responsibility.

The $P_{21}$ (2019) divided learning and innovation skills into four categories: critical thinking and problem-solving, creativity, collaboration, and communication which are known as the $4 \mathrm{Cs}$ skills. The ${ }_{4} \mathrm{Cs}$ help students develop the qualities of their success in the 21st Century college, work, and citizenship (Saxena, 2014). $\mathrm{P}_{21}$ has recognized the ${ }_{4} \mathrm{C}$ as the skills that American students need to graduate, in addition to conventional skills, in order to contribute 
successfully to America's growth and prosperity (Kivunja, 2015). The following subsection will explain each skill of the 4 Cs skills.

\subsubsection{Creativity and Innovation}

Creativity is referred to as trying new techniques to get things done, as well as innovation, and invention (Beth, 2016). Ideas, innovative ways of viewing an issue, and real actions to do new things that benefit the environment are all generated by creative skills (Rochmawati et al., 2019). Meanwhile, Barak \& Yuan (2020) described innovative thinking as a cognitive mechanism that contributes to the implementation of new or substantially changed concepts. In a fast-changing world, creativity and innovation is a critical catalyst for change. Bono (1995) as cited in Kivunja (2015) said that there would be no change if people did not have creativity, and without creativity, people would be stuck repeating the same pattern.

$\mathrm{P}_{21}$ (2019) characterized creativity and innovation by thinking creatively (i.e. use a wide range of idea generation techniques, create new and worthwhile ideas, elaborate the ideas), working creatively with others (i.e. communicate new ideas, be open to different perspectives, demonstrate originality, working by self-direction), and implementing innovations (i.e. contributing to the field).

\subsubsection{Critical Thinking and Problem Solving}

Critical thinking and problem-solving emphasize new approaches to problems and the integration of knowledge from various subjects and disciplines (Saxena, 2014). Critical thinking skills are the ability to think deeply from a range of viewpoints to come up with effective solutions (Rochmawati et al., 2019). American Philosophical Association in Facione (1990) defined critical thinking as an essential tool for inquiry, and it is a "liberating force in education and a powerful resource in one's personal and civic life." (p.3).

Someone could be a good critical thinker when she or he is observant by default, willing to challenge information, open-minded, versatile; someone who is truthful in confronting personal biases, cautious in making decisions, able to rethink, and consistent (Facione, 1990). There are some indicators of critical thinker proposed by $\mathrm{P}_{21}$ (2019), they are who reason effectively, use system thinking, make judgments and decisions (i.e. analyze and evaluate arguments, synthesize, interpret information, reflect on learning) and solve problems (i.e. solve the non-familiar problem, clarify the various point of view and lead to better solutions).

\subsubsection{Communication}

Communication skills are a person's action in conveying information to others including thoughts, queries, ideas, and solutions (Beth, 2016; Rochmawati et al., 2019). The simultaneous convergence of people from many cultures assisted by $21^{\text {st }}$ Century knowledge, media, and digital technology has made the necessity for effective communication more apparent and critical than in previous generations. Effective communication is required to effectively communicate the desired message to the target audience. Some research-based evidence abounds in pedagogy (Coulson, 2005; Cruickshank \& Kennedy, 1986; Muijs \& Reynolds, 2017; Wragg, 2006); indicated that communication skills, both interactional and transactional, are crucial for student's success both in the classroom and in life after graduation (Kivunja, 2015). To work in the global economy and be active citizens in the twenty-first century, students should develop culturally-centered communication skills. 
The indicator of a good communicator is communicating clearly. To communicate clearly, people should be able to effectively express thoughts and ideas using written, nonverbal, and oral communication skills; listen effectively to comprehend meaning; use communication for a variety of purposes; utilize various media and technologies; and communicate effectively in diverse settings (P21, 2019).

\subsubsection{Collaboration}

Collaboration is the way people perform effectively and respectfully in teams to solve problems or answer questions, to achieve a common goal, to accept joint responsibility for the completion of a mission by putting talent, expertise, and smarts to work (Beth, 2016; Ravitz et al., 2012; Rochmawati et al., 2019). Collaboration is regarded as an important learning outcome because it allows students to learn more deeply while teaching each other by correcting misunderstandings and clarifying misconceptions (Kulikovskikh et al., 2017). When collaboration is applied appropriately, it gives a positive impact on the people involved.

A successful collaboration can be indicated if they can collaborate with others $\left(P_{21}, 2019\right)$ including asserting the teamwork skills efficiently and respectfully with a diverse group of people, exercising flexibility and willingness to make compromises in achieving the shared goals, take shared responsibility and recognize each team member's contributions. Students with collaboration skills can develop diverse viewpoints and, as a result, they are able to express and defend their own ideas (Kulikovskikh et al., 2017).

\subsection{Online Project-based Learning}

Project-based learning is a student-centered instructional method where the students work collaboratively to accomplish certain objectives through a valuable project which is guided by an extended inquiry process (Bell, 2010; Kubiatko \& Vaculová, 2011; Moss, 1997). PBL enables students to learn through real-world projects while encouraging them, improving their problem-solving and reasoning skills, and empowering them to open their minds (Dilekli, 2020; Velez \& Power, 2020). There are four main stages in project-based learning (Bell, 2010; Stanly, 2000, Markham et al. 2011), it begins with starting the project (selecting the topic, drafting inquiry, deciding the final product), developing the project (gathering information, group discussion), reporting the project (presenting the final product, gaining some feedback), assessing the project (grading, self-evaluation, project-reflection).

Technology is used in online PBL as a means to an end and it allows for flexibility and virtual collaboration beyond the classroom (Waldman et al., 2016). The potency of today's technology allows for a more in-depth investigation. The current trend of PBL uses technology to help students accomplish a meaningful project while also practicing advanced real-world skills. In order to produce a meaningful project, Nikki (2020) propose some aspects should involved including challenging problem or question, sustained inquiry, authenticity, student voice and choice, reflection, critique and revision, and public product. In deciding the challenging inquiry, the teacher could utilize technology like an online conversation board to get input from students about what students already know and what they want to learn about the chosen topic. The process of sustained inquiry required the students to know how to use the web search engine responsibly and distinguish between trustworthy and untrustworthy sources. To get the authenticity in PBL, students might be led to a project that addresses issues in their school, neighborhood, or the world by using a digital map like Google Earth. 
Student voice and choice in creating the project need to be given as much as possible. The teacher might allow students to decide and use multimedia tools (Prezi Video, Canva) to express their creativity. In the process of project making, the students need to reflect and get critique and revision. Students should have time to check-in, debrief, and provide feedback. The feedback can come from an adult from outside the school, who is an expert in a projectrelated field. Online video conferencing tools (Zoom, Skype, Google Meet), enables collaboration with professionals from anywhere in the world. When the students. At the end of the project, the students should get the opportunity to display the product publicly through social media platforms (YouTube, Instagram, TikTok) so that they could interact with the authentic audience and get appreciation.

Even with limited teacher guidance, online PBL could be beneficial with peer-mentored learning (Morales et al., 2013). Ching \& Hsu (2013) found online PBL orient student's participation in peer feedback. Online PBL is believed to increase student's motivation, interest, and teamwork (Shih \& Tsai, 2017). Students can exchange and compare information, participate in debates and discussions, and maintain community morale by participating in online discussions (Afify, 2019).

Çakiroğlu \& Erdemir (2018) compiled some challenges in online PBL, those are struggling with time management (Rooij, 2009), project scope comprehension, resource finding, ideas reflection with the peer, priorities set, product co-construction (Heo et al., 2010; Lou, 2004). Online PBL requires support and appropriate feedback from the teachers. However, the low level of technology will limit the teacher's monitoring process (Wang et al., 2001).

English language teaching (ELT) objectives have shifted from just developing language skills. A conventional grammar lecture can be transformed into something in which teachers play an active role as facilitators and students become motivated, self-guided learners who keep within the curriculum's limitations by integrating the ${ }_{4} \mathrm{Cs}$ into EFL classrooms (Davila, 2016). Teachers can use fresh and innovative methods and ideas as part of this reconceptualization of the EFL classroom. Online PBL with the technology involved has great potential in developing students' $21^{\text {st }}$-Century skills, especially the $4 \mathrm{Cs}$ to prepare the students for the future. All of the stages in Online PBL could help the students to master those ${ }_{4} \mathrm{C}$ skills. When starting the project, students develop their critical thinking as well as creativity as they brainstorming. Students' creativity skills can be enhanced by suggesting and enriching activities such as brainstorming (Tin, 2013). Students' critical thinking skills are strengthened during the project development process by judging and selecting trustworthy or verified sources for their projects. Meanwhile, the collaboration and communication skills of the students are challenged in the group project development as well as in the project presentation. EFL classrooms are ideal conditions for improving students' communication abilities, as one of the primary aims of learning a foreign language is to be able to communicate in that language (Erdoğan, 2019).

\section{Research Methodology}

This study employed a descriptive case study method to explain the phenomenon in depth and within its real-world context. As said by Yin (2018) that a case study attempts to describe "how" and "why" a social phenomenon happens, this study employed case study to describe a phenomenon on how the implementation of online PBL in teaching ${ }_{4} \mathrm{Cs}$, as well as on how the students' view towards it. This study uses qualitative and primary data because the 
researcher wants to originally explore participants' perceptions and experiences in the online project-based learning implementation in the research setting. The data was obtained from the observation of the learning process supported by the result of the questionnaire distributed to the students. The study's findings place a greater emphasis on field data interpretation, allowing for data generalization. The researcher hopes that by presenting the students' perspectives on online PBL implementation in teaching ${ }_{4} \mathrm{Cs}$, the teacher and students would be able to explore how to improve the teaching and learning process.

\subsection{Participants}

The participants of this study were fifth-semester students of the English Education Department of a public university in Central Java in the academic year of 2020/2021. There are 33 students ( 22 females and 11 males) ranging in age from 19 to 23 . They were recruited purposefully based on several criteria: 1) Their native language is Bahasa Indonesia; 2) They are upper-intermediate level English Students; 3) They are fully participating in Online PBL so that their perception can be represented. All the participants underwent the same data collection procedure.

\subsection{Instruments}

Observation and field note-taking were conducted to collect the data by figuring out what was happening in the learning process via Google Meet and Learning Management System (LMS). The learning process was recorded by the lecturer in every meeting (40 minutes per session) in three months. There were 24 sessions in total. The researcher engaged in the role of the non-participant observer where the researcher's presence was unknown to the participants. The researcher took field notes consisting of the lecture and student's behavior pattern, the teaching and learning activities carried out by the lecturer and students, the evolving problems during class, and the strategies in the implementation of online PBL in teaching ${ }_{4} \mathrm{Cs}(\mathrm{RQ} 1)$. The activities and learning process were observed by re-watching the recordings thoroughly (39 recordings).

A 25-item Linkert-scale questionnaire was also used to investigate the students' experiences and their perspectives on the classroom activities. The items of the questionnaire were adapted from the indicators of learning and innovation skills $(4 \mathrm{Cs})$ proposed by Partnership for 21st-Century Learning $P_{21}$ (2019). The questionnaire consisted of 25 closed or structured questions typed in a set of forms with a four-point scale: Strongly Disagree, Disagree, Agree, and Strongly Agree. Goddard \& Melville (2001) argued that a four-scale questionnaire forced a decision. The researcher used a content (face) validity approach for the questionnaire's validity, which involves expert judgment in the establishment, examines the item's readability, and makes the items unambiguous. Meanwhile, the internal reliability of the questionnaire was measured by Cronbach's alpha with the alpha value of 0.8 which means the instrument has a good level of consistency $(\alpha>0.6)$. The instrument has also been tried out before being distributed. The researcher utilized Google Forms to distribute the questionnaire.

\subsection{Data Analysis Procedures}

The data from observation (field note) were analyzed by using an interactive analysis model proposed by Miles et al., (2014). The techniques involve three simultaneous and interactive flows of activity including data condensation, data display, and conclusion 
drawing/verification. The data from the questionnaire were analyzed both qualitatively and quantitatively. The responses to the open-ended questions were coded for further analysis. Meanwhile, the Likert scale responses were tabulated to find the total score per item using the formula $T x P n$, where $T$ is the total of the respondent's responses and $P n$ is the Likert Score. The maximum score $(Y)$ was found by multiplying the maximal likert score and number of respondent; while the minimum score $(\mathrm{X})$ was found by multiplying the minimal likert score and number of respondent. The researcher then used the formula based on Sugiyono (2009) to locate the index and interval.

\section{Findings}

\subsection{The Implementation of Online Project-Based Learning in Teaching 4Cs}

In this study, all of the teaching and learning processes were done in an online setting both synchronous (Google Meet, Zoom) and asynchronous (LMS, Open Course Ware). Based on the observation, the researcher found 5 stages of activity in the implementation of Online PBL: selecting the topic and the purpose, outlining the project, rehearsing the product, presenting the product, and assessing the product. Before starting the projects, the teachers provided an overview of the nature of public speaking, the ethics of speech, and how to be a good listener, and decided the final product. Since it was a Public Speaking class, the expected product was a speech video from each student. The stages of activities are described below.

The first stage was selecting the topic and the purpose. Nine general topics were provided in the LMS by the teacher including education, technology, crime, sports, politics, prejudice, science, music, and health. In synchronous learning, the students chose 3 topics among those nine. They were brainstorming to describe the general idea, specific purpose, and the central idea of those 3 topics. From 3 topics, they should narrow down into two topics that they really know, are eager to know, and have strong opinions on them. The two topics would be the final speech topic for their projects, but they were allowed to change their topic in the middle if they found other interesting topics. The purpose of the speech had been decided by the teacher as the common goal. Students were expected to make a purposive speech and an informative speech, so there would be two products with two different topics or the same topics.

After deciding the topics, the students were outlining the project, in this case, was their speech. At the very first, the students analyzed the audience of their speech and what the audience wanted to know about those topics. The teacher then let the students explore some relevant resources and evidence (articles, websites, scientific journals, orally cited sources, and books) to support their ideas. There were two steps in outlining the speech: first, the students filled the preparation outline and elaborate it into the speaking outline. Both steps were done in a google doc made and monitored by the teacher. In the preparation outline, they identify the special purpose, central idea, main point, and sub-point. Having the preparation done, the students elaborated them in speaking outline starting with an introduction (attention-getter, reveal topic, credibility position, thesis, preview main points), main point, conclusion (signaling the end of the speech, refer back to attention-getter, calling the audience to action, review the main points, make closing statements), and bibliography. 
When the students had already finished the speaking outline, they were rehearsing the product (their speech) with their friends via google meet. The teacher made six breakout rooms for students to form a rehearsal group. While a student was rehearsing his or her speech, the other students were paying attention and giving feedback. The feedback was expected to improve their final product. The rehearsal stage was divided into two-part. In the first part, the students rehearse the introduction and conclusion of their speech only. The purpose of the first part was to discuss the important component, the appropriate expression and transition words, and the useful phrases in the introduction and conclusion. Meanwhile, in the second part, the students rehearse their whole speech to get general feedback.

The fourth stage was presenting the product. As described previously, the students were asked to create two speech videos: persuasive $\&$ informative speeches. In the video making, the students were allowed to explore any video editing software to polish their speech videos. The teacher also suggested an online video presentation maker, Prezi Video, as one of the options. When they had finished making the videos, the students were asked to upload their speech on the teacher's YouTube channel so that the product could be shared beyond the classroom with public audiences. However, there's a problem with the submission of student's videos through YouTube. The submission was constrained because of Google account verification when signing in through another device. Therefore, the submission of the students' projects was shifted to provided folders in Google Drive.

The final stage was assessing the project which involved two activities: project grading and project reflection. The project was graded only by the teacher based on a scoring rubric of public speaking. The scoring rubric was shared with the students, so they knew what aspects would be assessed in their speech. In grading the product, the teacher considered students' matter (creativity/originality of introduction and conclusion, content, sequencing of ideas, suitability); manner (Voice-Pitch/Tone, Non-verbal communication, organization, preparation, pace/fluency, attitude); and method (structure, use of humor/satire/wit/surprise, use of digital aid, time). In project reflection, students got an opportunity to compare the expectation about this project to the reality of working on the project. They also shared problems encountered during the project.

From the observation, online project-based learning gave the students insight into digital literacy since the activities combined many technologies in the teaching and learning process. Although they could not meet in the face-to-face classroom, they were wellfacilitated by technology to communicate their ideas and give direct feedback. The students gained some important skills in the 21st Century during this project such as problem-solving skills, video-editing skills (creativity), and the skill to judge trustworthy resources which belong to critical thinking skills.

\subsection{Student's Perceptions toward the Implementation of Online Project-Based Learning in Teaching $4 \mathrm{Cs}$}

There are 25 questions with four options. The number of respondents is 33 . Therefore, the maximum score is 132 and the minimum score is 33 . The interval score is 25 and summarized as follows: 0\% - 24.99\% means strongly disagree, 25\%-49.99\% means disagree, 50\%-74.99\% means agree, $75 \%-100 \%$ means strongly agree. The data of students' perceptions after the implementation of Online Project-Based Learning in teaching ${ }_{4} \mathrm{Cs}$ are shown in Table 1. 
Amanda Ummu Haniah et al

Table 1. Students' Perceptions toward the Implementation of Online-Project Based Learning

\begin{tabular}{|c|c|c|c|c|c|c|c|c|}
\hline \multirow{2}{*}{\multicolumn{2}{|c|}{$\begin{array}{c}\text { No } \\
\text { Questions }\end{array}$}} & \multicolumn{4}{|c|}{ Responses } & \multirow{2}{*}{ Total } & \multirow{2}{*}{ Index } & \multirow{2}{*}{ Interva } \\
\hline & & SD & D & A & SA & & & \\
\hline \multicolumn{9}{|c|}{ Creativity and Innovation } \\
\hline \multicolumn{9}{|c|}{ Thinking Creatively } \\
\hline 1 & $\begin{array}{l}\text { I use a wide range of idea generation } \\
\text { techniques (such as brainstorming) }\end{array}$ & 1 & 8 & 51 & 44 & 104 & 78.79 & 59.69 \\
\hline 2 & I create old and useless ideas & 7 & 40 & 9 & 12 & 68 & 51.52 & 39.03 \\
\hline 3 & $\begin{array}{l}\text { I elaborate, refine, analyze, and evaluate } \\
\text { their ideas to improve and maximize } \\
\text { creative efforts }\end{array}$ & 0 & 8 & 48 & 52 & 108 & 81.82 & 61.98 \\
\hline \multicolumn{9}{|c|}{ Work Creatively with Others } \\
\hline 4 & $\begin{array}{l}\text { I did NOT develop, implement, and } \\
\text { communicate new ideas to others } \\
\text { effectively }\end{array}$ & 10 & 34 & 15 & 4 & 63 & $47 \cdot 73$ & 36.16 \\
\hline 5 & $\begin{array}{l}\text { I am unresponsive and NOT open to new } \\
\text { and diverse perspectives; I did NOT apply } \\
\text { group feedback into the work }\end{array}$ & 15 & 28 & 6 & 8 & 57 & 43.18 & 32.71 \\
\hline 6 & $\begin{array}{l}\text { I demonstrate originality and } \\
\text { inventiveness in work and understand the } \\
\text { real-world limits to adopting new ideas }\end{array}$ & 0 & 10 & 60 & 32 & 102 & 77.27 & 58.54 \\
\hline 7 & $\begin{array}{l}\text { I view failure as an opportunity to learn; } \\
\text { understand that creativity and innovation } \\
\text { is a long-term, cyclical process of small } \\
\text { successes and frequent mistakes }\end{array}$ & 0 & 2 & 42 & 72 & 116 & 87.88 & 66.57 \\
\hline \multicolumn{9}{|c|}{ Implement Innovations } \\
\hline 8 & $\begin{array}{l}\text { I did NOT use creative ideas to make a } \\
\text { meaningful and helpful contribution to } \\
\text { the field in which the innovation will occur }\end{array}$ & 13 & 26 & 15 & 8 & 62 & 46.97 & $35 \cdot 58$ \\
\hline \multicolumn{9}{|c|}{ Critical Thinking and Problem Solving } \\
\hline \multicolumn{9}{|c|}{ Reason Effectively } \\
\hline \multirow[t]{2}{*}{9} & $\begin{array}{l}\text { I use various types of reasoning } \\
\text { (inductive, deductive, etc.) as appropriate } \\
\text { to the situation }\end{array}$ & 0 & 10 & 66 & 24 & 100 & $75 \cdot 76$ & $57 \cdot 39$ \\
\hline & \multicolumn{8}{|l|}{ Use system thinking } \\
\hline 10 & $\begin{array}{l}\text { I analyze how parts of a whole interact } \\
\text { with each other to produce overall } \\
\text { outcomes in complex systems }\end{array}$ & 0 & 14 & 63 & 20 & 97 & $73 \cdot 48$ & 55.67 \\
\hline \multicolumn{9}{|c|}{ Make judgments and decisions } \\
\hline 11 & $\begin{array}{l}\text { I effectively analyze and evaluate } \\
\text { evidence, arguments, claims, and beliefs }\end{array}$ & 2 & 14 & 57 & 20 & 93 & 70.45 & $53 \cdot 37$ \\
\hline 12 & $\begin{array}{l}\text { I analyze and evaluate major alternative } \\
\text { points of view }\end{array}$ & 0 & 4 & 69 & 32 & 105 & $79 \cdot 55$ & 60.26 \\
\hline 13 & $\begin{array}{l}\text { I cannot synthesize and make connections } \\
\text { between information and arguments }\end{array}$ & 5 & 44 & 9 & 12 & 70 & 53.03 & 40.17 \\
\hline 14 & $\begin{array}{l}\text { I interpret information and draw } \\
\text { conclusions based on the best analysis }\end{array}$ & 0 & 8 & 51 & 48 & 107 & 81.06 & 61.41 \\
\hline
\end{tabular}


Students' Perception on the Implementation of Online Project-Based Learning

\begin{tabular}{|c|c|c|c|c|c|c|c|c|}
\hline 15 & $\begin{array}{l}\text { I cannot reflect critically on learning } \\
\text { experiences and processes }\end{array}$ & 7 & 34 & 18 & 12 & 71 & 53.79 & 40.75 \\
\hline & Solve Problems & & & & & & & \\
\hline 16 & $\begin{array}{l}\text { I cannot solve different kinds of non- } \\
\text { familiar problems in both conventional } \\
\text { and innovative ways }\end{array}$ & 6 & 34 & 24 & 8 & 72 & $54 \cdot 55$ & 41.32 \\
\hline 17 & $\begin{array}{l}\text { I identify and ask significant questions } \\
\text { that clarify various points of view and lead } \\
\text { to better solutions }\end{array}$ & 1 & 12 & 60 & 24 & 97 & $73 \cdot 48$ & 55.67 \\
\hline \multicolumn{9}{|c|}{ Communication } \\
\hline & \multicolumn{8}{|l|}{ Communicate Clearly } \\
\hline 18 & $\begin{array}{l}\text { I articulate thoughts and ideas effectively } \\
\text { using oral, written, and nonverbal } \\
\text { communication skills in a variety of forms } \\
\text { and contexts }\end{array}$ & 0 & 14 & 45 & 44 & 103 & 78.03 & 59.11 \\
\hline 19 & $\begin{array}{l}\text { I cannot listen effectively to interpret } \\
\text { meaning including knowledge, values, } \\
\text { attitudes, and intentions }\end{array}$ & 7 & 38 & 18 & 4 & 67 & 50.76 & 38.45 \\
\hline 20 & $\begin{array}{l}\text { I use communication for a range of } \\
\text { purposes (e.g. to inform, instruct, } \\
\text { motivate, and persuade) }\end{array}$ & 0 & 6 & 42 & 64 & 112 & 84.85 & 64.28 \\
\hline 21 & $\begin{array}{l}\text { I utilize multiple media and technologies, } \\
\text { and know-how to judge their } \\
\text { effectiveness a priority as well as assess } \\
\text { their impact }\end{array}$ & 0 & 4 & 57 & 48 & 109 & 82.58 & 62.56 \\
\hline 22 & $\begin{array}{l}\text { I cannot communicate effectively in } \\
\text { diverse environments (including multi- } \\
\text { lingual) }\end{array}$ & 4 & 36 & 30 & 4 & 74 & 56.06 & 42.47 \\
\hline \multicolumn{9}{|c|}{ Collaboration } \\
\hline & Collaborate with Other & & & & & & & \\
\hline 23 & $\begin{array}{l}\text { I demonstrate the ability to work } \\
\text { effectively and respectfully with diverse } \\
\text { teams }\end{array}$ & 0 & 10 & 54 & 40 & 104 & 78.79 & 59.69 \\
\hline 24 & $\begin{array}{l}\text { I am inflexible and unwilling to make } \\
\text { compromises to achieve a common goal }\end{array}$ & 10 & 30 & 15 & 12 & 67 & 50.76 & 38.45 \\
\hline 25 & $\begin{array}{l}\text { I assume shared responsibility for } \\
\text { collaborative work, and value the } \\
\text { individual contributions made by each } \\
\text { team member }\end{array}$ & 0 & 2 & 48 & 64 & 114 & 86.36 & 65.43 \\
\hline
\end{tabular}

Note: $S D=$ Strongly Disagree; $D=$ Disagree; $A=$ Agree; SA = Strongly Agree .

Table 1 shows the responses of 33 students to the 25 questions in the questionnaire. The students' response is categorized into four big themes related to the ${ }_{4} \mathrm{Cs}$ : creativity and innovation, critical thinking and problem solving, communication and collaboration. For each theme, there are several indicators of online PBL implementation helpfulness in teaching ${ }_{4} \mathrm{Cs}$. In the first theme, creativity and innovation, for the use of a wide range of idea generation techniques (such as brainstorming) is in the interval $59.69 \%$. It indicates that students agree Online PBL enables them to brainstorm the idea. They disagree (interval $39.03 \%)$ that their generated idea is old and useful. They believe their idea is new and worthwhile in doing the project during Online PBL. Online PBL also encourages students to 
elaborate, analyze, and evaluate their ideas (interval 61.98\%). The students show disagreement in item number 4 (interval 36.16\%), number 5 (interval $32.71 \%$ ), and number 8 (interval 35.58\%) which imply that they were able to develop and communicate their ideas effectively, consider different perspectives and give group feedback through Online PBL to make a helpful contribution in the field. The students agree that they could demonstrate creativity and are realistic about the limits of the situation (item 6 interval 58.54\%) and that they understand the importance of attempt as a part of the path to success, including failed attempts (item 7 interval 66.57\%) in working the project.

Online PBL in the second theme, critical thinking and problem solving, helps the students to reason effectively, use system thinking, make judgments and decisions, and solve problems. That inference is obtained from the student's agreement in some aspects; Online PBL enables students to use various types of reasoning as appropriate to the situation (item 9 interval 57.39\%), recognize and can manipulate parts of a system to come together to accomplish something (item 10 interval 55.67\%), analyze and evaluate evidence, arguments, claims, and beliefs effectively (item 11 interval 53.37\%), embrace learning about material from different points of view and are not judgmental in analyzing the material (item 12 interval 60.26\%), look at complex information and successfully draw conclusions and apply to situation (item 14 interval 61.41\%), identify and ask significant questions that clarify a various point of view and lead to a better solution in a variety of conditions (item 14 interval $55.67 \%$ ). By implementing Online PBL, the students can also apply the connections between information and arguments to support a perspective, reflect critically on learning experiences and processes, and utilize multiple techniques to engage in problem-solving and articulate reason for choosing. Those inferences are based on the disagreement of students for item number 13 (interval 40.17\%), 15 (interval 40.75\%), and 16 (interval 41.32\%).

For students' communication skills, it shows that they can communicate clearly. Students shows agreement on the positive statements in item number 18 (interval 59.11\%), 20 (interval $64.28 \%$ ), and 21 (interval 62.56\%), and disagreement on the negative statements in item number 19 (interval 38.45\%), and 22 (interval 42.47\%). Thus, Online PBL helps them in crafting and presenting a comprehensive multimedia presentation that uses both verbal and non-verbal communication, reflecting on the meaning, values, attitudes, and intentions of the message, using communication to inform, instruct, motivate, and persuade on multiple occasions using both verbal and non-verbal communication, crafting a product using multiple media and technologies and reflecting on the effectiveness and impact of the product, and communicating with others in diverse environments effectively.

Students show a positive perception of the last theme, collaboration. Online PBL supports them to collaborate with others by agreeing on items number 23 and 25 . Their answer on item number 24 implies that they agree that they listen to, share, and support others. Statements and responses are respectful and appropriate body language was exhibited (interval 56,69\%). Furthermore, they agree in item number 25 that they can participate and contribute to the group's work equally and also value all members' ideas and contributions (interval $65.43 \%$ ). They are willing to compromise with the group to accomplish a common goal; it was shown in their disagreement for item number 24 with an interval of $39.45 \%$.

According to the result of the questionnaire above, the students have a positive perception toward Online PBL implemented in teaching 4 Cs Public. Online PBL helped the student to 
gain the ${ }_{4} \mathrm{Cs}$ namely creativity and innovation, critical thinking, communication, and collaboration skills.

\section{Discussion}

Mastering 4 Cs has been a necessity for students in order to develop the qualities for success in college, work, and citizenship in the twenty-first century. The demand for 21st-century skills is significant, and it necessitates more forward-thinking innovation. Those skills must be incorporated into curriculum design, taught, and evaluated in education or anywhere else (Geisinger, 2016). The focus of educators today is to equip students with 21st-century skills (Zakaria et al., 2016). In an attempt to orient the teaching toward 21st Century Skills, the teacher needs to choose a teaching method that engages pupils in the teaching and learning process but also helps students to master the ${ }_{4} \mathrm{Cs}$. Besides, in order to make an enjoyable teaching and learning process, the teacher should be creative and innovative in using technology as media in the teaching method application. PBL is considered as one possible way to support a student's collaborative and communication skills through group work and social interaction to solve problems. PBL also encourages students to not only complete the phases of class projects that are relevant to their interests and needs but also to acquire the capacity to think critically and apply content knowledge. During PBL, the teacher and students have a direct interaction in developing the project in the classroom. As the COVID19 pandemic rapidly spreads, the interaction between the teacher and students is shifted into a total online classroom. Although the classroom has moved from face-to-face to online, PBL still can be implemented through Online PBL in which technology is used as a means to an end. This method was implemented in the public speaking class to help the students master the ${ }_{4} \mathrm{Cs}$.

Online PBL is an appropriate method to be implemented during this COVID-19 pandemic in order to help students master the ${ }_{4} \mathrm{Cs}$. The key element of the PBL method is student choice (Bell, 2010). In its implementation, Online PBL allows the students to explore ideas, abundant resources from the internet, and interesting media for their project. Students' interest in digging the online resources brings them into creative, critical, and independent thinkers as well as learners. As said by Shih \& Tsai (2017), Online PBL is believed to increase the motivation and interest of students. Online discussion is an important aspect of Online PBL because the students are able to discuss new ideas with their friends and are open to different points of view. Afify (2019) emphasized that in online discussion students can exchange and compare information, participate in debates and discussions, and maintain community morale. The teacher here functions as a facilitator or a guide who transfers information, organizes and monitors activities for practice by using technology such as Learning Management System and Google Meet. All of the stages in the Online PBL process are carried out by the students. The students are learning by doing, a PBL concept supported by Dewey (1938).

Based on the students' responses in the questionnaire, they have a positive perception toward Online PBL in helping them master the ${ }_{4} \mathrm{Cs}$. At the beginning of the project, students are brainstorming to generate a new and worthwhile idea. They also share the idea with their friends to get some feedback. It helps them to think creatively, communicate effectively, and work collaboratively. It is supported by Bell (2010) who argued that when brainstorming ideas, students develop basic skills of constructive communication, mutual respect, and 
teamwork. The integration of technology in PBL will help students accelerate not only their speaking achievement as part of their communication skills but also their creativity and collaboration skill needed in this 21st century (Winarsih, 2019).

Online PBL has the potential to help students improve their critical thinking and problemsolving skills. When developing the ideas, students gather any information, evidence, and claims from the internet. It requires proper media literacy and critical thinking skills (reasoning, analytical, and evaluating) as the effects of fake news have become a major issue (Scheibenzuber et al., 2021). During that stage of PBL, students learn how to navigate the Internet wisely, as well as how to distinguish between trustworthy and untrustworthy sites (Bell, 2010). Online PBL gives a chance for the students to solve real-world problems, making judgments and decisions, and connecting their prior knowledge with the new knowledge in the online environment which the information on some occasions brings more harm than good. Sirisrimangkorn (2018) revealed that PBL is student-centered and product-focused, with real-world connections that allow students to demonstrate their knowledge in practical ways. Indarti (2016) added that students should not only learn about making projects but also engage in the inquiry process, decision making, and problem-solving in PBL.

It is not only an interaction between students and teacher but also an intense interaction among students should also be maintained in Online PBL. Various applications and software offer their features to reinforce communication and collaboration in online learning such as video conferences and discussion forums. The result of the questionnaire proves that Online PBL helps them to articulate their ideas, communicate for different purposes and in a diverse environment, and utilize multiple media and technologies. It is supported by Capraro \& Slough (2013) in which PBL naturally utilizes communication skills because students must be able to effectively share ideas and information amongst group members to be successful. The students can give feedback to other friend's work in some breakout rooms in Google Meet which could save the teacher's time in giving feedback. Morales et al. (2013) stated that Online PBL allows peer-mentored learning even with limited teacher guidance. Projectbased learning and digital media in the context of EFL are an effective combination for improving students' self-confidence and communication skills (Lubis et al., 2020).

Nevertheless, there are some encountered problems in the Online PBL implementation. The technical issue becomes the major problem in the implementation of Online PBL. The teacher and students should make sure they have a strong connection to do the projects especially in conducting video conference meetings. Low connection makes them kicked out from the meeting and it causes them to miss out on some sessions. As Wang et al., (2001) said that low level of technology will limit the teacher's monitoring process. Some awkward moments were also found in the implementation of Online PBL when the students were asked by the teacher but they didn't give any response in synchronous learning. The teacher should be assertive in students' presence because some students are just lurking. Online communication sometimes triggers misinterpretation since there is no body language. To avoid the issues, the lecturer should provide a safe and supportive environment, encouraging all to participate (Benson \& Brack, 2010). Another issue found is time management which also has been identified in the findings of the research conducted by Rooij (2009). Some of the students are reluctant to make progress. Teachers need to have a kind of leadership that enables them to help a group of students move in the direction they want, recognize possible obstacles, or make recommendations without being defensive when the students decide to 
choose their ideas. If the teachers have no adequate experience in implementing Projectbased learning, sometimes they expect too much of a student's willingness to take care of the project which creates a too demanding situation for students.

\section{Conclusion}

Project-Based Learning has been one of the most popular instructional methods, as well as one of the most researched issues. The PBL method was mostly used in an offline or a blended learning environment in the previous study, and little is observed about PBL in a completely online learning environment. This study tries to describe how an instructional method named PBL was implemented in a fully online setting to be used in teaching ${ }_{4} \mathrm{Cs}$ that help students to develop the qualities of success in college, work, and citizenship required in the $21^{\text {st }}$ Century. There were five stages of the implementation of Online PBL in teaching ${ }_{4} \mathrm{Cs}$, starting from selecting the topic and the purpose, outlining the project, rehearsing the product, presenting the product, and assessing the product. Moreover, this study also presents the students' perception of the implementation of Online PBL in teaching ${ }_{4} \mathrm{Cs}$ which results in students' positive responses toward its implementation. Therefore, implementing Online PBL is highly recommended to teach the ${ }_{4} \mathrm{Cs}$ for the teachers. It is also beneficial for the students to help them master the ${ }_{4} \mathrm{Cs}$ as the essential skills in the $21^{\text {st }}$-Century. However, there are several aspects that should be considered such as technical support (internet connection, device compatibility, and software effectivity), teacher supervision, and time management.

\section{References}

Afify, M. K. (2019). The Influence of Group Size in the Asynchronous Online Discussions on the Development of Critical Thinking Skills, and on Improving Students' Performance in Online Discussion Forum. International Journal of Emerging Technologies in Learning, 14(5), 132-152. https://doi.org/10.3991/ijet.v14i05.9351

Barak, M., \& Yuan, S. (2021). A cultural perspective to project-based learning and the cultivation of innovative thinking. Thinking Skills and Creativity, 39, 100766. https://doi.org/10.1016/j.tsc.2020.100766

Bell, S. (2010). Project-Based Learning for the 21st Century: Skills for the Future. The Clearing House, 83(2), 39-43. https://doi.org/10.1080/00098650903505415

Beth, C. (2016, April 13). The ${ }_{4}$ Cs of $21 s t$ Century Skills. SimpleK12. https://www.simplek12.com/learning-theories-strategies/4cs-21st-century-skills/

Boaler, J. (1998). Open and closed mathematics: Student experiences and understandings. Journal for Research in Mathematics Education, 29(1), 41-62. https://doi.org/10.2307/749717

Bourn, D. (2018). Understanding global skills for 21st century professions. Springer.

Çakiroğlu, Ü., \& Erdemir, T. (2019). Online project based learning via cloud computing: exploring roles of instructor and students. Interactive Learning Environments, 27(4), 547566. https://doi.org/10.1080/10494820.2018.1489855

Capraro, R. M., \& Slough, S. W. (2013). Why PBL? why STEM? why now? an introduction to STEM project-based learning: An integrated science, technology, engineering, and mathematics (STEM) approach. In Brill. https://doi.org/10.1007/978-94-6209-143-6_1

Chen, C. H., \& Yang, Y. C. (2019). Revisiting the effects of project-based learning on students' 
academic achievement: A meta-analysis investigating moderators. Educational Research Review, 26, 71-81. https://doi.org/10.1016/j.edurev.2018.11.001

Ching, Y. H., \& Hsu, Y. C. (2013). Peer feedback to facilitate project-based learning in an online environment. International Review of Research in Open and Distance Learning, 14(5), 258-276. https://doi.org/10.19173/irrodl.v14i5.1524

Chu, S. K. W., Reynolds, R. B., Tavares, N. J., Notari, M., \& Lee, C. W. Y. (2016). 21st Century Skills Development Through Inquiry- Based Learning. 21st Century Skills Development Through Inquiry-Based Learning: From Theory to Practice, 1-204. https://doi.org/10.1007/978-981-10-2481-8

Cortázar, C., Nussbaum, M., Harcha, J., Alvares, D., López, F., Goñi, J., \& Cabezas, V. (2021). Promoting critical thinking in an online, project-based course. Computers in Human Behavior, 119, 106705. https://doi.org/10.1016/j.chb.2021.106705

Coulson, M. T. (2005). Developing Teachers' Cognitive Clarity and Communication Style Through an In Service Training Program. University of Newcastle.

Cruickshank, D. R., \& Kennedy, J. J. (1986). Teacher Clarity. Teaching and Teacher Education, 2(1), 43-67. https://doi.org/10.1016/0742-051X(86)90004-1

Davila, S. (2016, July 27). 21st century skills and the English language classroom. Pearson

English, 1. https://www.english.com/blog/21st-century-skills/

De Bono, E. (1995). Serious Creativity. Journal for Quality and Participation, 18(5), 12.

Dewey, J. (1938). Logic: The Theory Of Inquiry. Holt.

Dilekli, Y. (2020). Project-Based Learning. In Paradigm shifts in 21st century teaching and learning (pp. 53-68). IGI Global. https://doi.org/10.4018/978-1-7998-3146-4.choo4

Erdoğan, V. (2019). Integrating 4 C Skills of 21st Century into 4 Language Skills in EFL Classes. International Journal of Education and Research, 7(11), 113-124.

Facione, P. A. (1990). Critical Thinking: A Statement of Expert Consensus for Purposes of Educational Assessment and Instruction (pp. 315-423). ERIC document ED.

Fauziati, E. (2014). Methods of teaching English as a Foreign Language (TEFL): Traditional method, designer method, communicative approach, scientific approach. Era Pustaka Utama.

Geisinger, K. F. (2016). 21st Century Skills: What Are They and How Do We Assess Them? Applied Measurement in Education, 29(4), 245-249. https://doi.org/10.1080/08957347.2016.1209207

Goddard, W., \& Melville, S. (2001). Research Methodology: An Introduction (2nd ed.). Juta.

Guo, P., Saab, N., Post, L. S., \& Admiraal, W. (2020). A review of project-based learning in higher education: Student outcomes and measures. International Journal of Educational Research, 102, 101586. https://doi.org/10.1016/j.ijer.2020.101586

Heo, H., Lim, K. Y., \& Kim, Y. (2010). Exploratory study on the patterns of online interaction and knowledge co-construction in project-based learning. Computers and Education, 55(3), 1383-1392. https://doi.org/10.1016/j.compedu.2010.06.012

Indarti, I. (2016). Implementing Project-Based Learning (PBL) in Final Collection to Improve the Quality of Fashion Design Student. Innovation of Vocational Technology Education, 12(1), 22-30. https://doi.org/10.17509/invotec.v12i1.4500

Kivunja, C. (2015). Exploring the Pedagogical Meaning and Implications of the ${ }_{4}$ Cs "Super Skills" for the 21st Century through Bruner's 5E Lenses of Knowledge Construction to Improve Pedagogies of the New Learning Paradigm. Creative Education, 6(2), 224-239. https://doi.org/10.4236/ce.2015.62021 
Kubiatko, M., \& Vaculová, I. (2011). Project-based learning: characteristic and the experiences with application in the science subjects. Energy Education Science and Technology Part B: Social and Educational Studies, 3(1), 65-74.

Kulikovskikh, I. M., Prokhorov, S. A., \& Suchkova, S. A. (2017). Promoting collaborative learning through regulation of guessing in clickers. Computers in Human Behavior, 75, 81-91. https://doi.org/10.1016/j.chb.2017.05.001

Lou, Y. (2004). Learning to solve complex problems through between-group collaboration in project-based online courses. Distance Education, 25(1), 49-66. https://doi.org/10.1080/0158791042000212459

Lubis, N., Lubis, A., \& Purba, N. . (2020). Project-Based Learning Collaborated With Digital Media for Indonesian Efl Learners'Self-Confidence and Communication Skill. Jurnal $\begin{array}{llll}\text { Pendidikan Dan Pembelajaran } & \text { 10-17), }\end{array}$ https://doi.org/https://doi.org/10.32696/pgsd.v2i1.440

Miles, M. B., Huberman, A. M., \& Saldana, J. (2014). Qualitative Data Analysis: A Methods Sourcebook. Sage.

Moorhouse, B. L. (2020). Adaptations to a face-to-face initial teacher education course 'forced' online due to the COVID-19 pandemic. Journal of Education for Teaching, 46(4), 6og-611. https://doi.org/10.1080/02607476.2020.1755205

Morales, T. M., Bang, E. J., \& Andre, T. (2013). A One-year Case Study: Understanding the Rich Potential of Project-based Learning in a Virtual Reality Class for High School Students. Journal of Science Education and Technology, 22(5), 791-806. https://doi.org/10.1007/s10956-012-9431-7

Moss, D. (1997). Project Based Learning and Assessment: A Resource Manual for Teachers. Virginia Adult Education Resource Centers.

Muijs, D., \& Reynolds, D. (2017). Effective Teaching: Evidence and Practice (4th ed.). Sage.

Nikki, S. (2020, February 5). Essential Technology For Project-Based Learning. Tech \& Learning. https://www.techlearning.com/news/essential-technology-for-projectbased-learning

Owens, A. D., \& Hite, R. L. (2020). Enhancing student communication competencies in STEM using virtual global collaboration project based learning. Research in Science and Technological Education, 1-27. https://doi.org/10.1080/02635143.2020.1778663

P21. (2019). Framework for 21st century learning definitions. In Partnership for 21st Century Learning.

http://static.battelleforkids.org/documents/p21/P21_Framework_DefinitionsBFK.pdf

Panasan, M., Nuangchalerm, P., \& Muang, A. (2010). Learning Outcomes of Project-Based and Inquiry-Based Learning Activities. Journal of Social Sciences, 6(2), 252-255. http://files.eric.ed.gov/fulltext/ED509723.pdf

Ravitz, J., Hixson, N., English, M., \& Mergendoller, J. (2012). Using project based learning to teach 21 st century skills: Findings from a statewide initiative. American Educational Research Association Conference, Vancoucer, Canada.

Rochmawati, A., Wiyanto, \& Ridlo, S. (2019). Analysis of 21th Century Skills of Student on Implementation Project Based Learning and Problem Posing Models in Science Learning. Journal of Primary Education, 9(1), 58-67. https://journal.unnes.ac.id/sju/index.php/jpe/article/view/28753/12562

Rooij, S. W. van. (2009). Scaffolding project-based learning with the project management body of knowledge (PMBOK $\left.{ }^{\circledR}\right)$. Computers and Education, 52(1), 210-219. 
https://doi.org/10.1016/j.compedu.2008.07.012

Saxena, S. (2014, January 19). How Do You Teach the ${ }_{4}$ Cs to Students: Creativity and Innovation? (Part - 1) - Creativity and Innovation. EdtechReview. https://edtechreview.in/trends-insights/insights/914-how-do-you-teach-the-4Cs-tostudents-part-1-creativity-and-innovation

Scheibenzuber, C., Hofer, S., \& Nistor, N. (2021). Designing for fake news literacy training: A problem-based undergraduate online-course. Computers in Human Behavior, 121, 106796. https://doi.org/10.1016/j.chb.2021.106796

Schneider, R. M., Krajcik, J., Marx, R. W., \& Soloway, E. (2002). Performance of students in project-based science classrooms on a national measure of science achievement. Journal of Research in Science Teaching, 39(5), 410-422. https://doi.org/10.1002/tea.10029

Shih, W. L., \& Tsai, C. Y. (2017). Students' perception of a flipped classroom approach to facilitating online project-based learning in marketing research courses. Australasian Journal of Educational Technology, 33(5), 32-49. https://doi.org/10.14742/ajet.2884

Sirisrimangkorn, L. (2018). The Use of Project-based Learning Focusing on Drama to Promote Speaking Skills of EFL Learners. Advances in Language and Literary Studies, 9(6), 14-20. https://doi.org/10.7575/AIAC.ALLS.V.9N.6P.14

Songkram, N., Chootongchai, S., Khlaisang, J., \& Koraneekij, P. (2021). Education 3.o system to enhance twenty-first century skills for higher education learners in Thailand. Interactive Learning Environments, 29(4), 566-582. https://doi.org/10.1080/10494820.2019.1592197

Sugiyono. (2008). Metode Penelitian Pendidikan: (Pendekatan Kauntitatif, Kualitatif, R\&D). Alfabeta.

Tin, T. B. (2013). Towards creativity in ELT: The need to say something new. ELT Journal, 67(4), 385-397. https://doi.org/10.1093/elt/ccto22

Velez, G., \& Power, S. A. (2020). Teaching students how to think, not what to think: Pedagogy and political psychology. Journal of Social and Political Psychology, 8(1), 388-403. https://doi.org/10.5964/jspp.v8i1.1284

Waldman, T., Harel, E., \& Schwab, G. (2016). Getting their feet wet: trainee EFL teachers in Germany and Israel collaborate online to promote their telecollaboration competence through experiential learning. New Directions in Telecollaborative Research and Practice: Selected Papers from the Second Conference on Telecollaboration in Higher Education, 179-184. https://doi.org/10.14705/RPNET.2016.TELECOLLAB2016.505

Wang, M., Poole, M., Harris, B., \& Wangemann, P. (2001). Promoting online collaborative learning experiences for teenagers. Educational Media International, 38(4), 203-215. https://doi.org/10.1080/09523980110105079

Winarsih, W. W. (2019). Technology Based Learning in EFL Speaking Class. Jurnal Pendidikan Humaniora, 7(3), 95-100.

Wragg, E. . (2006). Classroom Teaching Skills. Routledge.

Yin, R. K. (2018). Case Study Research and Applications: Design and Methods (6th ed.). Sage.

Zakaria, S. M., Yunus, M. M., \& Nurhuda Mohamad Nazri, P. M. S. (2016). Students' Experience of Using Storybird in Writing ESL Narrative Text. Creative Education, 7(15), 2107-2120. https://doi.org/10.4236/ce.2016.715210 